(C) Group of authors, 2016

UDC 618,3-06:577.169

DOI - http://dx.doi.org/10.14300/mnnc.2016.11032

ISSN -2073-8137

\title{
HORMONES AND CYTOKINES IN FIRST-TRIMESTER PREGNANCIES COMPLICATED BY THREATENED ABORTION WITH DIFFERENT OUTCOMES
}

\author{
Dubrovina S. O. ${ }^{1}{ }^{2}$, Makluk A. M. ${ }^{1}$, Gimbut V. S. ${ }^{1}$, Krasilnikova L. V. ${ }^{2}$ \\ ${ }^{1}$ Rostov-on-Don Scientific Research Institute of Obstetrics and Pediatrics, \\ Russian Federation \\ 2 Rostov State Medical University, Russian Federation
}

\section{НЕКОТОРЫЕ ПОКАЗАТЕАИ ГОРМОНОВ И ЦИТОКИНОВ В ПЕРВОМ ТРИМЕСТРЕ БЕРЕМЕННОСТИ, ОСАОЖНЕННОЙ УГРОЗОЙ ПРЕРЫВАНИЯ}

\author{
С. О. Аубровина', 2 , А. М. МакАюк', В. С. Гимбут 1 , А. В. Красильникова ${ }^{2}$ \\ ${ }^{1}$ ниИ акушерства и гинекологии, Ростов-на-Аону, Российская ФеАерация \\ 2 Ростовский госУАарственный меАицинский университет, Российская ФеАерация
}

The purpose of the present study was to examine the profile of selected hormones and cytokines in serum of women with the first-trimester pregnancies complicated by threatened abortion. Levels of corticotropin-releasing hormone $(\mathrm{CRH})$, placental growth factor (PIGF), tumor necrosis factor alpha (TNF- $\alpha$ ), activin A, endothelial growth factor (VEGF), soluble variant of VEGF receptor-1 (sFlt-1), interleukin-2 (IL-2) and interleukin-6 (IL-6) were analyzed in serum of 24 women with adverse outcomes of the first-trimester pregnancies complicated by threatened abortion (group I). Results were compared with the corresponding levels of 35 women with successful results of first-trimester complicated pregnancies (group II) and 26 women with first-trimester uncomplicated pregnancy (group III). We did not find out significant differences in the levels of IL-2, IL-6 and activin A levels between all groups. Serum TNF- $\alpha$ levels in group II were significantly lower compared with group III. It was revealed sFIt-1 levels were approximately two-fold higher in the control group as opposed to those found in other observed groups. In collating with group III, VEGF and CRH levels were significantly lower in group II and higher in group I. The PIGF levels were significantly lower in groups I and II, compared with group III. In first-trimester pregnancies complicated by threatened abortion with adverse outcome, alteration of maternal angiogenic factors, TNF- $\alpha$ and CRH levels, compared to first-trimester uncomplicated pregnancy and the first-trimester pregnancies complicated by threatened abortion with a successful outcome, is relevant to the missed abortion occurrence.

Key words: missed abortion, cytokines, angiogenic factors, hormons

Цель настоящего исследования состояла в изучении профиля отдельных гормонов и цитокинов в сыворотке крови женщин в первом триместре беременности, осложненной угрожающим абортом, с различными исходами. Проанализированы уровни кортикотропин-рилизинг гормона (CRH), фактора роста плаценты (ФРП), фактора некроза опухоли- $\alpha$ (ФНО- $\alpha$ ), активина А, сосудисто-эндотелиального фактора-А (СЭФР), растворимой формы рецептора СЭФР (sFlt-1), интерлейкина-2 (ИЛ-2) и интерлейкина-6 (ИЛ-6) в сыворотке крови 24 женщин с угрожающим абортом и неблагоприятным исходом в первом триместре беременности (I группа). Результаты сравнивали с соответствующими показателями 35 женщин с благоприятными исходами угрозы прерывания беременности (II группа) и 26 женщин с неосложненной беременностью (III группа). Значительных различий в уровнях ИЛ-2, ИЛ-6 и активина А между всеми группами не было найдено. Уровень сывороточного ФНО- $\alpha$ во II группе был достоверно ниже по сравнению с группой III. Уровень sFlt-1 был примерно в два раза выше в контрольной группе по сравнению со всеми остальными группами. По сравнению с III группой уровни СЭФР и CRH были значимо ниже в группе II и выше в I группе. Уровень ФРП был достоверно ниже в группах I и II по сравнению с III группой. В первом триместре беременности у женщин с неблагоприятным исходом угрожающего аборта изменения концентрации факторов ангиогенеза, CRH и ФНО- $\alpha$ в сыворотке крови по сравнению с неосложненной беременностью и угрожающим абортом с благоприятным исходом связаны с прекращением развития беременности.

Ключевые слова: неразвивающаяся беременность, цитокины, факторы ангиогенеза, гормоны

A pproximately $70 \%$ of spontaneous conceptions are lost prior to completion of the firsttrimester. Implantation failure and preclinical losses account for $\mathbf{8 5} \%$ of total pregnancy losses and clinically missed abortion for $15 \%$ [1]. The physiological outburst of oxidative stress associated with the onset of the maternal arterial circulation might have the significance in triggering normal placental differentiation [2]. In approximately twothirds of early pregnancy failures, there is anatomical 
evidence of defective placentation that is mainly characterized by a thinner fragmented trophoblast shell, and reduced cytotrophoblast invasion of the lumen at the tips of the spiral arteries. This process leads to the premature onset of the maternal circulation throughout the placenta in the cases of missed abortions [3]. Endothelial growth factor (VEGF) induces angiogenesis. It interacts with the soluble variant of VEGF receptor-1 (VEGFR-1 or sFlt1) and KDR (VEGFR-2) to favor the endothelial cell proliferation, migration and vascular permeability. KDR is well-known as the central VEGF receptor in angiogenesis while Flt-1 has a supporting role. During pregnancy, sFlt-1 suppresses VEGF and thereby limits its activity [4]. Placental growth factor (PIGF) is the most abundantly regulated factor in uncomplicated first- trimester decidua [5].

Cytokines are involved in implantation as they are in ongoing pregnancy and delivery. Scientists discuss the relevance of cytokines to infertility and recurrent pregnancy loss [6]. It is well-known that the intrauterine infections associated with pregnancy complications. Infection of the maternal-fetal unit stimulates an upregulation of inflammatory cytokines such as TNF- $\alpha$, IL-6 and members of the IL-1 group. IL-2 lost sampled from the maternal circulation in mid-pregnancy can be interpreted as a prospective marker for histologic chorioamnionitis [7]. In serum of women with first-trimester pregnancies complicated by threatened abortion, the levels of IL-1 $\beta$ and TNF- $\alpha$ were significantly higher in women with adverse outcome at admission, compared with other groups with successful results at discharge and with first-trimester uncomplicated pregnancy [8]. Activin A (Act A) rapidly releases into the circulation after intravenous injection of LPS, it might represent a determinant component of the early inflammatory pathway. At the same time activin A presents in the serum at high levels during the first-trimester of human pregnancy. Decreasing activin A levels correlate both with an ongoing missed abortion and ectopic pregnancy [9]. An emerging role for the hypothalamic neuropeptide corticotropin-releasing hormone $(\mathrm{CRH})$ in implantation has been recently described. This neuropeptide is produced by the pregnant and the non-pregnant uterus, and its numerous roles in female reproductive physiology and pathophysiology are gradually being clarified. Recently, $\mathrm{CRH}$ was found to be significantly higher in cases of spontaneous abortion [10].

By investigating the profile of IL-2, TNF- $\alpha, \mathrm{IL}-6, \mathrm{CRH}$, activin A, sFIt-1, PIGF and VEGF levels in serum of women with the first-trimester complicated by threatened abortion with adverse and successful outcomes and uncomplicated pregnancies, this study intended to make clear the role of imbalance between cytokines and hormone in the obstetric outcome.

Material and Methods. It was a prospective, nonrandomized, case-control clinical study conducted at the institute's departments: outpatients, maternity hospital and research laboratory facilities. 81 women in the first-trimester pregnancy were enrolled in the study. The gestational age of all the women studied, based on ultrasound measurements, ranged between 7 and 11 weeks. The study included 59 women admitted to the Institute outpatient department with symptoms of threatened abortion such as the presence of vaginal bleeding and closed cervical os at the same time. An active heart activity of fetus was detected by ultrasonographic examination. Treatment of all women at the hospitalization included bed rest, application of spasmolytics and gestagens. Evaluation of well-being during pregnancy was performed with $\beta$-human chorionic gonadotropin evaluation and ultrasound assessment. Twenty-four (group I) out of 59 women with threatened abortion subsequently presented acute bleeding, and this resulted in spontaneous abortion or clinical and ultrasonographic signs of nonviable pregnancy after 7-12 days from admission. These women underwent evacuation of the products of conception. Thirty-five out of 59 women with threatened abortion (group II) were discharged when vaginal bleeding discontinued, and a viable fetus was confirmed by U/S. 22 pregnant women who had no any complaints and had a good clinical observation history were recruited with controls as in (group III).

All groups met the same exclusion criteria: women receiving any medication, with chromosomal or uterine structural abnormalities, hormonal disorders, with autoimmune or other systemic diseases were excluded from the study. The study was approved by the Local Ethics Committee, and all patients gave their consent to take part in this investigation at admission.

Venous blood samples were collected at admission from women of all groups using $10 \mathrm{ml}$ sterile tubes without anticoagulant. The serum was treated according to uniform standards and stored at $-75^{\circ} \mathrm{C}$ until analyzed.

Serum concentrations of IL-2 were determined by enzyme-linked immunosorbent assays (ELISA) according to the manufacturer's instructions (BMS221HS, Bender MedSystems Austria, Europe). The range of measurement was $0.94-60.0 \mathrm{pg} / \mathrm{ml}$, the intra- and inter assay coefficients of variation were $5.7 \%$ and $6.2 \%$, respectively and the analytical sensitivity of the method was $0.4 \mathrm{pg} / \mathrm{ml}$. Serum concentrations of TNF- $\alpha$ were determined using the same method. There were no detectable human TNF- $\alpha$ levels found. The intra- and inter assay coefficients of variation were $7.7 \%$ and $8.1 \%$, respectively, and the analytical sensitivity was $5.0 \mathrm{pg} / \mathrm{ml}$. Serum concentrations of IL-6 were determined of ELISA kit (BMS213/2TEN, Bender MedSystems Austria, Europe). The range of measurement was non-detectable $-12.7 \mathrm{pg} / \mathrm{ml}$, the intra- and inter assay coefficients of variation were $3.4 \%$ and $5.2 \%$, respectively, and the analytical sensitivity was $0.92 \mathrm{pg} / \mathrm{ml}$. Free serum levels of VEGF were measured by highly specific immunoassays (KHG0112, BioSource International, Inc. USA). The range of measurement was $0-120 \mathrm{pg} / \mathrm{ml}$, the intra- and inter assay coefficients of variation were $4.7 \%$ and $8.1 \%$, respectively, and the analytical sensitivity was $<5 \mathrm{pg} / \mathrm{ml}$. Serum concentrations of PIGF were assessed by immunoassay kit (KHG0021, BioSource International, Inc. USA). The range of measurement was $15.6-1000 \mathrm{pg} / \mathrm{mL}$, the intra- and inter assay coefficients of variation were $4.3 \%$ and $5.5 \%$, respectively, and the analytical sensitivity was $<15.6 \mathrm{pg} / \mathrm{ml}$. Serum concentrations of activin-A were assessed by an immunoassay kit (MCA1426KZZ, Oxford Bio-Innovation, LTD). The range of measurement was $0-5 \mathrm{ng} / \mathrm{ml}$, the inter assay coefficients of variation was $<10 \%$, respectively, and the analytical sensitivity was $<78 \mathrm{ng} / \mathrm{ml}$. Serum concentrations of sVEGF-R1 (sFlt-1) were determined by a high sensitivity ELISA kit (BMS268/2, Bender MedSystems Austria, Europe). There are no detectable sVEGF-R1 levels found in healthy donors, the intra- and inter assay coefficients of variation were $5.1 \%$ and $5.4 \%$, respectively, and the analytical sensitivity was $0.06 \mathrm{ng} / \mathrm{ml}$. Serum concentrations of $\mathrm{CRH}$ were assessed, in duplicate, by a high sensitivity Immunoassay kit (H-2435, Bachem Group, USA). The range of measurement was $0-25 \mathrm{ng} / \mathrm{ml}$ and the analytical sensitivity was $1.4 \mathrm{ng} / \mathrm{ml}$.

Distribution of all markers were tested for normality with the use of the Kolmogorov-Smirnov test (KS-test). Statistically significant differences in median values between groups were calculated using Spearman RankOrder Correlation (unpaired differences) or Wilcoxon test (paired differences) and $\mathrm{P}$-values less than 0.05 were 
considered as significant. The results are expressed as the median and range. ROC curves for the prediction of different outcomes of the first-trimester pregnancies complicated by threatened abortion were produced for all markers. The markers were dichotomized based on the concentration providing the optimal prediction. Relative risks were obtained for categorical data. A generalized linear model with a log link function for the combined prediction model was used instead of a standard conditional logistic regression so that adjusted relative risk estimates could be obtained. Analyses were computed using STATA 6.
Results and Discussion. The average age was similar among all studied groups: 30.7 (range 21-40) years in group I, 31.6 (range 21-40) years in group II, and 28.3 (range 21-40) years in group III. Median gestational age was the same in all studied groups: 8.2 (range 7-11) weeks in group I, 8.7 (range $7-11$ ) weeks in group II, and 8.5 (range $7-11$ ) weeks in group III.

The serum values of IL-2 levels were similar among all studied groups (group I vs group II: $\mathrm{P}=0.610$, group I vs group III: $\mathrm{P}=0.520$ and group II vs group III: $\mathrm{P}=0.847$ ) (Table 1).

Quality of model of analyzing parameters and their ratio between group I and III

\begin{tabular}{|l|c|c|c|c|c|c|c|c|}
\hline & Activin A & TGF- $\alpha$ & PIGF & IL-2 & Il-6 & CRH & VEGF & sFIt-1 \\
\hline AUC* & 0.699 & 0.691 & 0.578 & 0.565 & 0.552 & 0.547 & 0.650 & 0.851 \\
\hline SE** & 0.0889 & 0.0898 & 0.0974 & 0.0981 & 0.0985 & 0.0986 & 0.0938 & 0.0661 \\
\hline $95 \%$ CI*** & $0.521-0.842$ & $0.513-0.836$ & $0.400-0.743$ & $0.388-0.731$ & $0.375-0.720$ & $0.371-0.716$ & $0.471-0.803$ & $0.690-0.948$ \\
\hline Test cut-off & $\leq 1.25$ & $\leq 8.48$ & $\leq 26.86$ & $>14.39$ & $>1.064$ & $>20.81$ & $>31.54$ & $\leq 0.392$ \\
\hline Sensitivity & 70.59 & 58.82 & 52.94 & 76.47 & 52.94 & 52.94 & 47.06 & 88.24 \\
\hline $95 \%$ CI*** & $44.0-89.7$ & $32.9-81.6$ & $27.8-77.0$ & $50.1-93.2$ & $27.8-77.0$ & $27.8-77.0$ & $23.0-72.2$ & $63.6-98.5$ \\
\hline Specificity & 83.33 & 83.33 & 83.33 & 55.56 & 66.67 & 77.78 & 88.89 & 77.78 \\
\hline $95 \%$ CI*** & $58.6-96.4$ & $58.6-96.4$ & $58.6-96.4$ & $30.8-78.5$ & $41.0-86.7$ & $52.4-93.6$ & $65.3-98.6$ & $52.4-93.6$ \\
\hline +PV**** & 80.0 & 76.9 & 75.0 & 61.9 & 60.0 & 69.2 & 80.0 & 78.9 \\
\hline $95 \%$ CI*** & $51.9-95.7$ & $46.2-95.0$ & $42.8-94.5$ & $38.4-81.9$ & $32.3-83.7$ & $38.6-90.9$ & $44.4-97.5$ & $54.4-93.9$ \\
\hline -PV***** & 75.0 & 68.2 & 65.2 & 71.4 & 60.0 & 63.6 & 64.0 & 87.5 \\
\hline $95 \%$ CI*** & $50.9-91.3$ & $45.1-86.1$ & $42.7-83.6$ & $41.9-91.6$ & $36.1-80.9$ & $40.7-82.8$ & $42.5-82.0$ & $61.7-98.4$ \\
\hline
\end{tabular}

${ }^{*}$ - area under curve; ${ }^{* \star}$ - standard error; ${ }^{* \star *}$ - confidential interval; ${ }^{* \star * *}$ - positive predictive value; ${ }^{* \star \star \star *}$ - negative predictive value.

Serum concentrations of IL-6 were not significantly different among all groups also (group I vs group II: $\mathrm{P}=$ 0.603 , group I vs group III: $\mathrm{P}=0.641$, group II vs group III: $\mathrm{P}=0.414)$.

It was found that serum values of TNF- $\alpha$ were significantly higher in group III in comparison with group II $(\mathrm{P}<0.001)$ but were comparable amongst other groups: group I versus group II $(P=0.303)$, group I versus group III $(P=0.073)$.

Activin A concentrations were similar between all groups (group I versus group II: $P=0.441$, group I versus group III: $\mathrm{P}=0.070$, group II versus group III: $\mathrm{P}=0.052$ ).
The levels of VEGF in group I were significantly higher as compared with group II $(\mathrm{P}<0.001)$, and group II vs group III $(P<0.001)$. There were no significant differences amongst the group I vs group III $(\mathrm{P}=0.286)$.

The values of PIGF in group I were significantly higher when compared to group II $(P<0.05)$, and group III vs group II $(P<0.001)$, but did not differ in group I vs group III $(P=0.273)$.

Serum concentrations of sVEGF-R1 in group III were significantly higher compared to group I $(P<0.001)$, group II versus group I $(\mathrm{P}<0.001)$, and did not differ in group II versus group III $(\mathrm{P}<0.143)$ (Table 2$)$.

Quality of model of analyzing parameters and their ratio between group II and III

\begin{tabular}{|l|c|c|c|c|c|c|c|c|}
\hline & Activin A & TNF- $\alpha$ & PIGF & Il-2 & IL-6 & CRH & VEGF & sFIt-1 \\
\hline AUC* & 0.744 & 0.711 & 0.921 & 0.529 & 0.559 & 0.771 & 0.779 & 0.643 \\
\hline SE** & 0.0757 & 0.0786 & 0.0464 & 0.0838 & 0.0828 & 0.0729 & 0.0720 & 0.0827 \\
\hline $95 \%$ CI*** & $0.606-0.854$ & $0.570-0.827$ & $0.813-0.977$ & $0.387-0.668$ & $0.416-0.695$ & $0.636-0.876$ & $0.643-0.881$ & $0.499-0.770$ \\
\hline Test cut-off & $<=2.33$ & $<=10.29$ & $<=21.38$ & $>19.56$ & $>1.154$ & $<=17.44$ & $<=4.16$ & $<=0.434$ \\
\hline Sensitivity & 88.57 & 60.00 & 88.57 & 57.14 & 45.71 & 71.43 & 57.14 & 65.71 \\
\hline $95 \%$ CI*** & $73.3-96.8$ & $42.1-76.1$ & $73.3-96.8$ & $39.4-73.7$ & $28.8-63.4$ & $53.7-85.4$ & $39.4-73.7$ & $47.8-80.9$ \\
\hline Specificity & 55.56 & 83.33 & 94.44 & 61.11 & 77.78 & 83.33 & 94.44 & 77.78 \\
\hline $95 \%$ CI*** & $30.8-78.5$ & $58.6-96.4$ & $72.7-99.9$ & $35.7-82.7$ & $52.4-93.6$ & $58.6-96.4$ & $72.7-99.9$ & $52.4-93.6$ \\
\hline+ PV**** & 79.5 & 87.5 & 96.9 & 74.1 & 80.0 & 89.3 & 95.2 & 85.2 \\
\hline $95 \%$ CI*** & $63.5-90.7$ & $67.6-97.3$ & $83.8-99.9$ & $53.7-88.9$ & $56.3-94.3$ & $71.8-97.7$ & $76.2-99.9$ & $66.3-95.8$ \\
\hline -PV***** & 71.4 & 51.7 & 81.0 & 42.3 & 42.4 & 60.0 & 53.1 & 53.8 \\
\hline $95 \%$ CI*** & $41.9-91.6$ & $32.2-70.9$ & $58.1-94.6$ & $23.0-63.5$ & $25.5-60.8$ & $38.2-79.2$ & $34.4-71.2$ & $33.4-73.4$ \\
\hline
\end{tabular}
value.

${ }^{\star}$ - area under curve; ${ }^{* *}$ - standard error; ${ }^{* \star *}$ - confidential interval; ${ }^{* \star * *}$ - positive predictive value; ${ }^{* \star \star * *}-$ negative predictive 
Finally, serum levels of $\mathrm{CRH}$ in group I were significantly higher compared to group II $(\mathrm{P}<0.05)$, group III versus group II $(\mathrm{P}<0.001)$ but did not differ in group I versus group III $(P<0.540)$.

For optimal prediction purposes, all markers were dichotomized based on ROC-curves into high or low levels. The area under the ROC-curve measures the ability of the marker to classify correctly study groups. According to the results of Roc analysis, the ideal parameter for any difference between I and III groups is sFlt-1 $\leq 0.392 \mathrm{ng} / \mathrm{ml}$, the difference between II and III groups is PIGF $\leq 21.38 \mathrm{pg} / \mathrm{ml}$. It is very important that there is a variation in markers between groups I and II: ratio VEGF/sFlt-1, CRH/sFlt-1, sFlt-1/PIGH, IL-6/VEGF (Table 3).

Quality of model of analyzing parameters and their ratio between group I and II

Table 3

\begin{tabular}{|c|c|c|c|c|c|c|c|c|}
\hline & Activin A & TNF- $\alpha$ & PIGF & IL-2 & IL-6 & $\mathrm{CRH}$ & VEGF & sFlt-1 \\
\hline AUC* & 0.532 & 0.573 & 0.741 & 0.528 & 0.532 & 0.750 & 0.810 & 0.820 \\
\hline SE** & 0.0853 & 0.0864 & 0.0778 & 0.0865 & 0.0853 & 0.0770 & 0.0697 & 0.0576 \\
\hline $95 \% \mathrm{CI}^{* * *}$ & $\begin{array}{c}0.388- \\
0.672\end{array}$ & $\begin{array}{c}0.428- \\
0.709\end{array}$ & $\begin{array}{c}0.601- \\
0.853\end{array}$ & $\begin{array}{c}0.384- \\
0.668\end{array}$ & $\begin{array}{c}0.388- \\
0.672\end{array}$ & $\begin{array}{c}0.610- \\
0.859\end{array}$ & $\begin{array}{c}0.677- \\
0.905\end{array}$ & $\begin{array}{c}0.689- \\
0.913\end{array}$ \\
\hline Test cut-off & $\leq 0.518$ & $>0.228$ & $>21.38$ & $>14.14$ & $\leq 1.37$ & $>17.44$ & $>4.78$ & $\leq 0.278$ \\
\hline Sensitivity & 47.06 & 82.35 & 58.82 & 76.47 & 88.24 & 82.35 & 94.12 & 82.35 \\
\hline $95 \% \mathrm{CI}^{* * * *}$ & $23.0-72.2$ & $56.6-96.2$ & $32.9-81.6$ & $50.1-93.2$ & $63.6-98.5$ & $56.6-96.2$ & $71.3-99.9$ & $56.6-96.2$ \\
\hline Specificity & 74.29 & 40.00 & 88.57 & 42.86 & 31.43 & 71.43 & 60.00 & 77.14 \\
\hline $95 \% \mathrm{CI}^{* * *} *$ & $56.7-87.5$ & $23.9-57.9$ & $73.3-96.8$ & $26.3-60.6$ & $16.9-49.3$ & $53.7-85.4$ & $42.1-76.1$ & $59.9-89.6$ \\
\hline$+\mathrm{PV} * * * *$ & 47.1 & 40.0 & 71.4 & 39.4 & 38.5 & 58.3 & 53.3 & 63.6 \\
\hline $95 \%$ CI*** & $23.0-72.2$ & $23.9-57.9$ & $41.9-91.6$ & $22.9-57.9$ & $23.4-55.4$ & $36.6-77.9$ & $34.3-71.7$ & $40.7-82.8$ \\
\hline -PV***** & 74.3 & 82.4 & 81.6 & 78.9 & 84.6 & 89.3 & 95.5 & 90.0 \\
\hline $95 \% \mathrm{CI}^{*} * *$ & $56.7-87.5$ & $56.6-96.2$ & $65.7-92.3$ & $54.4-93.9$ & $54.6-98.1$ & $71.8-97.7$ & $77.2-99.9$ & $73.5-97.9$ \\
\hline
\end{tabular}
value.

${ }^{\star}$ - area under curve; ${ }^{* \star}$ - standard error; ${ }^{* \star *}$ - confidential interval; ${ }^{\star \star \star *}$ - positive predictive value; ${ }^{\star \star \star \star *}-$ negative predictive

Cytokines are responsible for determining the nature of an immune response. They have been shown to influence all stages of reproduction and playing a fundamental role in pregnancy outcome. We have limited information concerning the role of IL-2 in recurrent spontaneous abortion (RSA). IL-6 data is contradictory. Elevated IL-6 serum levels at the maternal-fetal interface were associated with high abortion rates in mice [11]. It was found high in human MPLR by the Raghupathy group [12], but other studies have not found such a correlation with either abortion or early implantation failure [13]. Our results suggest that IL-2 and IL-6 are not correlated with a different outcome of the first-trimester pregnancies complicated by threatened abortion [8]. No significant differences in IL-6 levels were found in serum of pregnant women at $<20$ weeks of gestation with RSA, in comparison with non-pregnant women who have had a past history of habitual abortion as well as healthy non-pregnant women. Moreover, production of lipopolysaccharide, stimulated by IL-6, in serum of non-pregnant women with RSA was similar to women with a history of successful pregnancies without missed abortion [15]. Unaltered serum IL-6 levels have observed in women with threatened abortion compared to those of normal pregnant and non-pregnant women; at the same time significantly lower values were been reported in women with missed abortion. Our results suggest that there is no any Th2 difference in first-trimester $[6,8]$.

The data of this study demonstrates that maternal TNF- $\alpha$ levels are higher in first-trimester uncomplicated pregnancies than in the first-trimester pregnancies complicated by threatened abortion with a successful outcome. TNF- $\alpha$ levels were increased at the onset of spontaneous abortion, as compared to normal pregnancies $[14,15]$. TNF- $\alpha$ levels that are similar to those in normal pregnancy were reported in threatened abortion with a good results [16]. The elevated maternal TNF- $\alpha$ levels in first-trimester pregnancies complicated by threatened abortion with a poor outcome, in comparison with uncomplicated pregnancies and the first-trimester pregnancies complicated by threatened abortion with a good outcome, further endorse the abortogenic role of this cytokine [8]. Our results support this finding. It is very important that we examined the profile of selected cytokines in maternal serum at admission but spontaneous abortion did occur between 7-12 days later. For the better understanding of the role of TNF- $\alpha$ in spontaneous abortion further investigation is required.

Activin A serves as a useful diagnostic marker. Its level is detectable commencing after a positive pregnancy test. While activin A plays an intricate role in various inflammatory processes. IL-6 and IL-8 production in amnion explants was found to be significantly stimulated by activin $A$ [17]. However, in another system, activin $A$ did not significantly alter the production of pro- and anti-inflammatory chemokines and cytokines [18]. In our study, serum values of activin A were not significantly different between the first-trimester pregnancies complicated by threatened abortion with the different outcomes at the admission and uncomplicated pregnancy. So we have the opinion despite the well-known fact that activin A level in early pregnancy correlates with the success of pregnancy but the underlying processes remain elusive [18].

The present study showed the maternal VEGF levels in a first-trimester uncomplicated pregnancy elevated in comparison to the first-trimester pregnancies complicated by threatened abortion with a successful outcome. We have found the significantly higher serum concentrations of sVEGF-R1 in the group with an uncomplicated pregnancy as compared with the group with the complicated pregnancies with an adverse outcome, and in the group with the complicated pregnancies with successful outcome versus the complicated pregnancies with adverse result. Decidual vascular adaptation to implantation is essential for a successful pregnancy and commences during the receptive secretory phase of the menstrual cycle. Disturbances in vascular development play an important role in the pathogenesis of missed abortions [19]. The vascularization pattern varied in the decidual secretory endometrium, decidua parietalis and decidua basalis of missed abortion cases and controls. These differences correlated with the differential expression of several angiogenic molecules including sFlt-1. The decreased ves- 
sel density and increased vascular surface might also be due to an altered balance between the angiogenesis regulating factors. More angiogenic factors show expression in missed abortion compared with controls [20,21]. Our findings agreed with this opinion and also showed the adjusting function of VEGF receptors at the protein level [4].

PIGF, the most important regulated factor in the uncomplicated first trimester decidua [5], is not differentially expressed and appears not to be involved in the pathogenesis of missed abortions [21]. However according to our data, the serum values of PIGF were significantly higher in an uncomplicated pregnancy compared with the first-trimester pregnancy complicated by threatened abortion with successful outcome, and in the group with the first-trimester pregnancy complicated by threatened abortion and adverse outcome compared to the first-trimester pregnancy complicated by threatened abortion with successful outcome.

$\mathrm{CRH}$ is the principal mediator of the stress response. $\mathrm{CRH}$ is produced by the pregnant and the non-pregnant uterus, and its roles in female reproductive physiology and pathophysiology have been clarified $[22,23]$. In our research in the group with the first-trimester pregnancy complicated by threatened abortion and successful outcome serum $\mathrm{CRH}$ levels are significantly depressed in comparison to those of the group with uncomplicated pregnancies. Serum values of $\mathrm{CRH}$ in the group with adverse outcome of complicated pregnancy and were significantly higher as compared to those of group with successful outcome. Our results suggested that systemic or uterine stress might induce the local release of $\mathrm{CRH}$ which therefore represents a causative link between stress and abortion. This peptide is produced at the implantation site [24, 25] and decidua normally does not express FasL, this mechanism appears to be active in abortions, but is blocked in normal pregnancy. $\mathrm{CRH}$ is able to induce the expression of FasL in decidual lympho-

\section{References}

1. Macklon N. S., Geraedts J. P., Fauser B. C. Conception to ongoing pregnancy: the 'black box' of early pregnancy loss. Hum Reprod Update. 2002;8:333-343.

2. Jauniaux E., Hempstock J., Greenwold N., Burton G. J. Trophoblastic oxidative stress in relation to temporal and regional differences in maternal placental blood flow in normal and abnormal early pregnancies. Am J Pathol. 2003; $162: 115 e 25$.

3. Jauniaux E., Burton G. J. Pathophysiology of histological changes in early pregnancy loss. Placenta. 2005;26:114-123.

4. Maynard S. E., Min J., Merchan J., Lim K. H., Li J. et al. Excess placental soluble fms-like tyrosine kinase 1 (sflt1) may contribute to endothelial dysfunction, hypertension, and proteinuria in preeclampsia. J Clin Invest. 2003:111:649-658.

5. Plaisier M., Rodrigues S., Willems F., Koolwijk P., van Hinsbergh V. W. et al. Different degrees of vascularisation and their relation to the expression of VEGF, PIGF, angiopoietins and their receptors in first-trimester decidua. Fertil Steril. 2007;88:176-187.

6. Chaouat G., Dubanchet S., Ledee N. Cytokines: Important for implantation? J Assist Reprod Genet 2007:24:491-505.

7. Gargano J. W., Holzman C., Senagore P., Thorsen P., Skogstrand K. et al. Mid-pregnancy circulating cytokine levels, histologic chorioamnionitis and spontaneous preterm birth. J Reprod Immunol. 2008;79:100-110.

8. Vitoratos N., Papadias C., Economou E., Makrakis E., Panoulis C. et al. Elevated circulating IL-1 $1 \beta$ and TNF-alpha, and unaltered IL-6 in first-trimester pregnancies complicated by threatened abortion with an adverse outcome. Mediators of Inflammation. 2006; Article ID 30485:1-6.

9. Florio P., Severi F. M., Bocchi C., Luisi S., Mazzini M. et al. Single serum activin a testing to predict ectopic cytes and thus potentiate its ability to kill extravillous trophoblasts. In the latter case, $\mathrm{CRH}$ is instead able to promote the survival of extravillous trophoblasts through the opposite mechanism [24]. Elevated levels of $\mathrm{CRH}$ found in abortion placentas, activate endometrial mast cells to secrete abortogenic tryptase and IL-8. Thus, there is association between the elevation of placental $\mathrm{CRH}$ and the pathophysiology leading to abortion.

According to the results of ROC analysis the optimum parameter for any difference between groups with adverse outcomes and uncomplicated pregnancy is sFlt$1 \leq 0.392 \mathrm{ng} / \mathrm{ml}$, the optimum difference between the first-trimester pregnancies complicated by threatened abortion with good outcomes and uncomplicated pregnancy is PIGF $\leq 21.38 \mathrm{pg} / \mathrm{ml}$. It is critical that there is a difference in multiple markers between the first-trimester pregnancies complicated by threatened abortion with poor results and with good outcomes: ratio VEGF/sFlt-1, $\mathrm{CRH} / \mathrm{sFlt}$-1, sFlt-1/PIGH, IL-6/VEGF. This difference may use as a specific marker to expose preclinical abortion.

Conclusions. There is an alteration of the maternal cytokine and hormone levels in the first-trimester pregnancy complicated by threatened abortion with adverse outcome, as compared to complicated pregnancy with successful result and first-trimester uncomplicated pregnancy. Further prospective studies including a significant number of the first-trimester threatened abortions with good and adverse outcome and a multivariable logistic regression analysis are required to discover negative predictors of obstetric outcome. We hope that elucidation of the mechanisms governing early placentation in health and disease might be a basis for new therapeutic modalities for the treatment of pregnancy complications associated with a defective placentation.

Acknowledgements. Authors would like to express great appreciation to Yuri Nadedov for his help in editing the article.

pregnancy. J Clin Endocrinol Metab. 2007;92:17481753

10. Minas V., Jeschke U., Kalantaridou S.N., Richter D.U., Reimer T. et al. Abortion is associated with increased expression of FasL in decidual leukocytes and apoptosis of extravillous trophoblasts: a role for $\mathrm{CRH}$ and urocortin. Molecular Human Reproduction 2007;13:9:663-673.

11. Zenclussen A. C., Blois S., Stumpo R., Olmos S., Arias K. et al. Murine abortion is associated with enhanced interleukin-6 levels at the feto-maternal interface. Cytokine. 2003;24:150-160.

12. Raghupathy R., Makhseed M., Azizieh F., Hassan N., AlAzemi M. et al. Maternal Th1- and Th2-type reactivity to placental antigens in normal human pregnancy and unexplained recurrent spontaneous abortions. Cell Immunol. 1999;196:122-130.

13. Makrigiannakis A., Minas V., Kalantaridou S. N., Nikas G., Chrousos G. P. Hormonal and cytokine regulation of early implantation. Trends Endocrinol Metab. 2006;17:178185.

14. Von Linsingen R., Bompeixe E. P., Bicalho Mda G. A case-control study in IL6 and TGFB1 gene polymorphisms and recurrent spontaneous abortion in southern Brazilian patients. American Journal of Reproductive Immunology. 2005;53(2):94-99.

15. Daher S., de Arruda Geraldes Denardi K., Blotta M. H. Cytokines in recurrent pregnancy loss. Journal of Reproductive Immunology. 2004;62(1-2):151-157.

16. Gucer F., Balkanli-Kaplan P., Yuksel M., Sayin N. C., Yuce M. A. et al. Maternal serum levels of tumor necrosis factor-alpha and interleukin-2 receptor in threatened abortion: a comparison with normal and pathologic pregnancies. Fertility and Sterility. 2001;76(4):707-711.

17. Keelan J. A., Zhou R. L., Evans L.W., Groome N. P., Mitchell M. D. Regulation of activin A, inhibin A, and follistatin production in human amnion and choriodecidual 
explants by inflammatory mediators. J Soc Gynecol Investig 2000;7(5):291-296.

18. Segerer S. E., Müller N., van den Brandt J., Kapp M., Dietl J., Reichardt H. M. et al. The glycoprotein-hormones activin $A$ and inhibin A interfere with dendritic cell maturation. Reproductive Biology and Endocrinology. 2008;6:17.

19. Zygmunt M., Herr F., Munstedt K., Lang U., Liang O. D. Angiogenesis and vasculogenesis in pregnancy. Eur $J$ Obstet Gynecol Reprod Biol. 2003;110:S10-S18.

20. Zhang E. G., Smith S. K., Baker P. N., Charnock-Jones D. S. The regulation and localization of angiopoietin-1, -2, and their receptor Tie2 in normal and pathologic human placentae. Mol Med. 2001;7:624-635.

21. Plaiser M., Dennert I., Rost E., Koolwijk P., van Hinsbergh V. W. et al. Decidual vascularization and the expression of angiogenic growth factors and proteases in first trimester spontaneous abortions. Human reproduction. 2009;24:1:185-197.

22. Gravanis A., Margioris A. N. The corticotropin-releasing factor (CRF) family of neuropeptides in inflammation: potential therapeutic applications. Curr Med Chem. 2005:12:1503-1512.

23. Kalantaridou S. N., Makrigiannakis A., Zoumakis E., Chrousos G. P. Stress and the female reproductive system. J Reprod Immunol. 2004:62:61-68.

24. Makrigiannakis A., Zoumakis E., Kalantaridou S., Coutifaris C., Margioris A. N. et al. Corticotropin-releasing hormone promotes blastocyst implantation and early maternal tolerance. Nat Immunol. 2001;2:1018-1024.

25. Bamberger C. M., Minas V., Bamberger A. M., Charalampopoulos I., Fragouli Y. et al. Expression of urocortin in the extravillous human trophoblast at the implantation site. Placenta. 2007;28:127-132.

\title{
About authors:
}

Dubrovina Svetlana, MD, PhD, Professor, main researcher;

tel.: +7(863)2504200; e-mail: s.dubrovina@gmail.com

Makluk Aliya, MD, gynecologist of Scientific Research Institute

of Obstetrics and Pediatrics» of Ministry of Health of Russian Federation;

tel.: +7(863)2993542; e-mail: secretary@rniiap.ru

Gimbut Vitaliy, MD, gynecologist of Scientific Research Institute;

tel.: +7(863)2993542; e-mail: secretary@rniiap.ru

Krasilnikova Liliya, MD, postgraduated student;

tel.: +7(863)2504200; e-mail: cool.dalida2014@yandex.ru

\section{PECULIARITIES OF THE DEVELOPMENT OF CHRONIC PELVIC PAIN RELATED COMPONENTS IN PERITONEAL ENDOMETRIOSIS}

\author{
Kutsenko I. I., Kravtsova E. I., Musolyants R. A., Nazarenko E. I.
}

Kuban State Medical University, Krasnodar, Russian Federation

\section{ОСОБЕННОСТИ ФОРМИРОВАНИЯ КОМПОНЕНТОВ ХРОНИЧЕСКОЙ ТАЗОВОЙ БОАИ ПРИ ПЕРИТОНЕААЬНОМ ЭНАОМЕТРИОЗЕ}

\section{И. И. Куценко, Е. И. Кравцова, Р. А. Мусольянц, Е. И. Назаренко \\ Кубанский госуАарственный МеАицинский университет, КрасноАар, Российская ФеАерация}

The article includes the results of the complex study of cytokine and serotonin status as pathogenic chronic pelvic pain related factors in peritoneal endometriosis. The distinctive features of the development of the syndrome associated with the severity and character of the pelvic pain due to peritoneal endometriosis have been revealed.

Key words: chronic pelvic pain, peritoneal endometriosis, cytokines, serotonin

Представлены результаты комплексного исследования цитокинового и серотонинового статусов как факторов, участвующих в формировании патогенетических компонентов хронической тазовой боли при перитонеальном эндометриозе. Выявлены особенности формирования данного синдрома в зависимости от интенсивности и характера течения тазовой боли при перитонеальном эндометриозе.

Ключевые слова: хроническая тазовая боль, перитонеальный эндометриоз, цитокины, серотонин 